TEME, г. XLIII, бр. 4, октобар - децембар 2019, стр. 1109-1124

Прегледни рад https://doi.org/10.22190/TEME191018066G

Примљено: 18. 10. 2019.

UDK 343.26(497.11)

Ревидирана верзија: 19. 10. 2019.

Одобрено за штампу: 1. 12. 2019.

\title{
LIFE IMPRISONMENT AS AN ANSWER TO CONTEMPORARY SECURITY CHALLENGES - THE (IN)ADEQUACY OF THE RETRIBUTIVE APPROACH -
}

\author{
Zdravko V. Grujić \\ University of Priština temporary settled in Kosovska Mitrovica, \\ Faculty of Law, Kosovska Mitrovica, Serbia \\ zdravko.grujic@pr.ac.rs
}

\begin{abstract}
Contemporary Serbian criminal legislation characterizes the concept of expansionism - the strengthening of the prescribed penalties and extending the limits of criminal repression ("punitive populism"), as legislative response to the trends of criminality, potential security challenges and public attitudes on the adequacy of the social response to the phenomenon of crime. The latest in a series of legislative changes envisages the introduction of life imprisonment as a new penalty in the criminal sanction system and, at the same time, the abolition of (long-term) imprisonment from thirty up to forty years. The severity of the criminal law reaction is reflected not only in the introduction of life imprisonment, but also in the prohibition of conditional release for the convicted, to life imprisonment for certain serious crimes, although such a solution is often challenged in comparative and international jurisprudence. The aim of this paper is to review the justification of introducing life imprisonment in our criminal legislation and to point out the (in)acceptability of certain normative solutions; to determine the potential scope and effects of life imprisonment as penalty, that is, to critically analyze the adequacy of the retributive approach in relation to the trends of criminality and contemporary security challenges.
\end{abstract}

Key words: life imprisonment, prison sentence, security challenges.

\section{КАЗНА ДОЖИВОТНОГ ЗАТВОРА КАО ОДГОВОР НА \\ САВРЕМЕНЕ БЕЗБЕДНОСНЕ ИЗАЗОВЕ - (НЕ)АДЕКВАТНОСТ РЕТРИБУТИВНОГ ПРИСТУПА}

\section{Апстракт}

Савремено српско кривично законодавство обележава концепт експанзионизма - константног пооштравања казни и проширивање граница кривичноправне репресије, тзв. казнени популизам, који се појављује као реакција законодавца на стање криминалитета, потенцијалне безбедносне изазове и став опште јавности о адекватности друштвеног одговора на феномен криминалитета. Последња у низу измена и допуна предвиђа увођење казне доживотног затвора у систем кривичних 
санкција и, истовремено, укидање казне (дуготрајног) затвора у трајању од тридесет до четрдесет година. Оштрина кривичноправне реакције огледа се не само у увођењу доживотног затварања већ и у забрани условног отпуштања осуђених на казну доживотног затвора за одређена кривична дела (код којих је прописана казна доживотног затвора), иако је овакво решење често оспоравано у упоредној и међународној јуриспруденцији. Циљ овог рада је да преиспита оправданост увођења казне доживотног затвора у српско кривично законодавство и укаже на (не)прихватљивост одређених нормативних решења, да укаже на потенцијалне домете и ефекте доживотног затварања, односно, да анализира адекватност ретрибутивног приступа у односу на стање криминалитета и савремене безбедносне изазове.

Кључне речи: казна доживотног затвора, казна затвора, безбедносни изазови.

\section{INTRODUCTORY REMARKS}

Contemporary criminal legislation in the Republic of Serbia is characterized by frequent amendments, which also include the Criminal Code (Official Gazette 85/2005, 88/2005 - correc. 107/2005 - correc., 72/2009, 111/2009, 121 / 2012, 104/2013, 108/2014 and 94/2016 - hereinafter CC), which was part of the amended 2005 Serbian criminal law legislation. The basic characteristic of the numerous amendments to the $\mathrm{CC}$, viewed from the current perspective, is the introduction of new incriminations and the toughening of the prescribed penalties as legislative reaction with regards to the criminal trends and the security challenges our society faces. This approach is, undoubtedly, not isolated in comparative legislation and practice, and it is practically a consequence of the populist response to the problem of combating crime and crime control, which, as a trend started in the 1980s, has appeared in many contemporary criminal justice systems, and it has been developing to this day. In essence, it is the affirmation of the neoclassical principle of just, fair and rigorous punishment, referred to in the literature as "just deserts" (Hirsch, 1985: 29), which suppresses the offender's resocialisation and social reintegration to the secondary purpose of punishment and, as the primary goal and purpose of punishing reaffirms the 'deserved' and just sentence proportional to the gravity of the crime.

In other words, the contemporary criminal law is characterized by criminal expansionism - prescribing a large number of new offenses, deviating from some basic principles of criminal law and using criminal law as a solo ratio rather than the ultima ratio (Stojanović, 2010: 37), a "security orientation" directed towards the elimination of the causes of potential danger and increasing repressiveness (Soković, 2011: 217, 218), hence, "punitive populism" (Ristivojević, 2013: 319) can be taken to be the basic criminal-political orientation of the legislator.

In this context, it is no surprise that life sentence has been introduced in the criminal sanctions system and (long-term) imprisonment ranging from thirty to forty years, as the most severe penalty in the system, has been abolished. Long-term imprisonment scope and effectiveness could not even be challenged, since the period after its introduction has been shorter than the one necessary for any analysis or research. On the other hand, although the general public has been 
appalled by the recent brutal crimes with children as victims, influencing, undoubtedly, the tenacity in the standpoint for introducing life imprisonment, this process lacked the presentation of a comparative statistical analysis on the most serious crimes as a potential argument in favor of introducing such a sentence as necessary and justified. Therefore, in this paper, we will present the statistical indicators of the general criminality trends and the dynamics of violent crimes in the previous period as indicators that can lead us to conclude on the adequacy of the retributive approach to punishing and the necessity of introducing life imprisonment in Serbian criminal legislation.

\section{LIFE IMPRISONMENT IN SERBIAN CRIMINAL LEGISLATION}

The public opinion has welcomed the possibility of introducing life imprisonment, because experience so far indicates that the public has always expressed the need for repressive punishment as much as possible (Stojanović, 2015: 7). Life imprisonment was not introduced in Serbian legislation after the abolition of the death penalty, first by legislative activities on the federal level in 1993 and 2001 (when it was replaced by a prison sentence of up to 40 years), or more precisely, in 2002, when it was abolished for the remaining crimes prescribed in the Criminal Law. The new CC from 2005 kept the maximum sentence of forty years of imprisonment, while most of the other contemporary national criminal legislation, after the abolition of the death penalty, adopted a different approach - introducting life imprisonment (Van Zyl Smit, Appleton, 2019). ${ }^{1}$

Introducing life imprisonment in the Republic of Serbia was announced in 2015, when the Ministry of Justice presented the public with the Draft Law on Amendments to the Criminal Code, which, among other things, provided for the changes of the criminal sanctions system and introduced life imprisonment as a new penalty. After a public debate on the text of the Draft, critical and divided opinions of the expert public on justifying the introduction (such as the unique suggestion of the judges of the Criminal Division of the Supreme Court of Cassation not to introduce the sentence into the system, Dragičević-Dičič, 2015: 15), there was a withdrawal of the Draft Law from further procedure.

However, a series of severe crimes that have taken place in recent years, especially the monstrous murders of children, influenced the legislator decision during 2019, without holding a public hearing, to submit the Draft and adopt the Law of Amending the Criminal Code and to introduce the sentence of life

\footnotetext{
${ }^{1}$ From 51 countries (or territories) in Europe, 42 of them, including now the Republic of Serbia, have the sentence of life imprisonment in their legislation. European countries in which it is not prescribed are: Andorra, Bosnia and Herzegovina, Croatia, Faroe Islands, Montenegro, Norway, San Marino and the Vatican. In the African continent, it is not prescribed in 3 out of 55 national systems, in Asia in 3 out of 29 countries. Only 2 out of 22 Caribbean states, 6 out of 8 Central American states, 1 out of 18 Oceania countries, 1 out of 4 North America and 7 out of 12 South American countries do not have the life sentence prescribed.
} 
imprisonment into the criminal legislation (Grujić, Blagić, Bojanić: 2019, f. 4). ${ }^{2}$ The father of one of the murdered girls, lobbying via the foundation named after the victim, launched a media campaign and organized the submission of the people's initiative with over 158,000 signatures, which turned out to be crucial in the implementation of the accelerated procedure for changing the $\mathrm{CC}$, the implementation of the previous idea of the legislator to finally introduce life imprisonment in the criminal sanctions system. ${ }^{3}$

The amended Article 43 of the CC, among other penalties, now provides for life imprisonment and it will be possible to impose it starting from December $1^{\text {st }} 2019$ when the provisions of the new law come into force. The new Article 44a of the CC, entitled "Life imprisonment" provides that for the most serious crimes and the most serious forms of serious crimes, in addition to the imprisonment, the punishment of life imprisonment may be prescribed, except in case of a person who did not reach the age of twenty-one at the time of committing the crime, or in the cases where the law provides that the penalty may be mitigated (Article 56, paragraph 1 , item 1 of the $\mathrm{CC}$ ), or where there are no grounds for the remittance of punishment. Therefore, by virtue of a number of phenomenological and etiological characteristics of minors, their criminality must be distinguished from the criminality of the adults (Kostić, 2011: 476). This means that this punishment cannot be imposed on juvenile offenders or offenders in the category of young adults due to the specificities of their position in criminal legislation.

Although the legal formulation provides that life imprisonment can only be prescribed as an addition to the sentence of imprisonment, the Law of Amending CC virtually abolishes the sentence of long-term imprisonment from thirty up to forty years and replaces it with life imprisonment. It is contrary to the principle of judicial determination of sentence to prescribe life imprisonment as the only penalty for a particular crime, since in this case the court does not even have the possibility of determining the duration of the sentence (Risimović, Kolarić, 2016: 2). Life imprisonment represents a sentence which cannot be the standard of determination, but it can only be imposed if the court considers it justified and necessary (or "fair and proportionate").

\footnotetext{
${ }^{2}$ The public was horrified by the murder cases: Tijana Jurić, a 15-year-old girl from Subotica who was abducted, raped and killed in Bajmok on the night between July $25^{\text {th }}$ and $26^{\text {th }} 2014$ while visiting her grandparents. Her body was found on August $7^{\text {th }}, 12$ days after the disappearance. The killer first hit the girl with his car, kidnapped and got the girl into the car, raped, then strangled, and disposed of the body in an improvised garbage dump near Sombor, 23 kilometers from the place where she was abducted; The three-year-old Anđelina Stefanović, a girl from the village of Vratarnica near Zaječar, who was murdered on July $9^{\text {th }}, 2016$. Murderer, a neighbor, took the girl away from the celebration of a child's birthday into a nearby forest. According to the media, the killer first raped the girl and then smashed the child's head using a stone he found on site. After executing the murder, the killer changed his clothes and returned to the birthday party.

3 “"Tijana Đurić Foundation": https://tijana.rs/fondacija/, Access: September 30 2019.
} 
Life imprisonment taking over the role and function of long-term sentences duration of which ranges from thirty to forty years, two questions are raised. The first being whether the frequency of imposed imprisonment of forty years and its participation in the structure of imposed prison sentence can be an indicator for the future application of life imprisonment. The second question is whether the abolition of thirty up to forty years' imprisonment would affect the more frequent imposition of life imprisonment because the courts would be limited in determination with (only one remaining) general maximum of twenty years of imprisonment (Đokić, 2016: 223).

Table 1. Long-term imprisonment in the Republic of Serbia 2007-2016

\begin{tabular}{lrrrrrrrrrrrrrr}
\hline $\begin{array}{l}\text { Long-term } \\
\text { Imprisonment }\end{array}$ & 2006 & 2007 & 2008 & 2009 & 2010 & 2011 & 2012 & 2013 & 2014 & 2015 & 2016 & 2017 & 2018 & Total \\
\hline 40 years & 11 & - & 1 & 4 & 10 & 3 & 2 & 1 & 2 & 4 & 5 & 2 & 3 & 48 \\
30 to 40 years & - & 7 & 14 & 20 & 16 & 5 & 12 & 9 & 11 & 13 & 9 & 11 & 7 & 134 \\
\hline
\end{tabular}

Source: Statistical Office of the Republic of Serbia

According to the Statistical Office of the Republic of Serbia (Bulletin, 2015; Report, 2019) presented in the table 1, the total number of 48 prison sentences of forty years were imposed between 2006 and 2018. The highest number of 11 was recorded in 2006, and in 2007 no penalty was imposed. On average, there were 3.69 sentences of forty years of imprisonment each year. When it comes to prison terms of between thirty to forty years, a total of 134 sentences were imposed in the same period, or, on average, just over 10 annually. The highest number was 20 imposed in 2009, and the smallest 5 in 2011.

The presented data confirms that the imposition of imprisonment from thirty up to forty years stands as the exception, not the rule. Namely, in the observed period, the total number of 110,372 prison sentences were imposed in the criminal proceedings. When comparing the absolute number of those sentenced to imprisonment, it is easy to find that the share of thirty to forty years of imprisonment in the structure of prison sentences was $0.165 \%$, while this percentage is lower for the forty years' sentence $-0.043 \%$. This data may be an indicator that, in the case of similar crime rates and trends and the unchanged criminal policy of the courts after introducing the new sentence in the $\mathrm{CC}$, life imprisonment would be applied only as an exception, which was presumably the intention of the legislator when defining how to prescribe it. This could, at least for the time being, delay any potential problems in the process of implementing life imprisonment in penitentiary institutions where the penalty would be executed.

The introduction of life imprisonment in criminal legislation, and its regulation, required the amendments of several other provisions of the CC. Thus, the provisions in relations to the conditional release were amended. The adopted solutions can be considered controversial. 
Firstly, it is the period of time served in prison after which the sentenced person can initiate conditional release proceedings. Namely, Article 46, paragraph 2 of the CC, provides optional (facultative) conditional release for persons sentenced to life imprisonment, or, a convicted person may initiate conditional release proceedings only after serving twenty-seven years. Although there are different decisions in comparative law about the length of time a prisoner must spend in prison before they can initiate release, ${ }^{4}$ the question is raised of what has led our legislator to set that limit to exactly twenty-seven years. Possible explanations for this could be found in different international standards, so when it comes to the served period in prison, the internationally "established standard" is set to the maximum of twenty-five years, unless a shorter period is provided for by national law, based on the jurisprudence of the European Court of Human Rights (e.g. Vinter and Others v. United Kingdom, or the decision adopted in the Rome Statute of the International Criminal Court (UN Doc. A \& CONF, 183/9).

The legislator's explanation is that life imprisonment is considered to be a tougher sentence than forty years of imprisonment and that therefore it is prescribed as astricter period. Thus, mathematical calculations set a period of twenty-seven years, which is four months longer than was necessary for the sentence of forty years of imprisonment. This example may be paradigmatic in pointing out the legislator's approach of proposing and adopting "systematic", but in practice, ad hoc and unsustainable solutions.

Another controversial solution is the prohibition of the conditional release of persons sentenced to life imprisonment for specific crimes prescribed by the law. Thus, Article 46, paragraph 5 of the $\mathrm{CC}$ provides that a court may not release a person convicted to life imprisonment for: aggravated murder (Art. 114, para. 1, p. 9), rape (Art. 178, para. 4), sexual intercourse with a helpless person (Art. 179, para. 3), sexual intercourse with a child (Art. 180, para. 3), and sexual intercourse through abuse of position (Art. 181, para. 5). By imposing a ban, another form of life imprisonment is introduced in our criminal justice system - de jure life imprisonment without parole fully irreducible - LWOP (Van Zyl Smith, Appleton, 2019: 41).

In this regard, new issues have been raised. First being the choice of crimes. The above mentioned crimes qualify by means of grave consequence - the death of a child, a pregnant woman or a person in a disadvantaged position (e.g. children and students in relation to their teacher - Vuković, Đokić, 2015: 888), and represent, without doubt, the ones which were selected as a consequence of pressure by the families of children. However,

\footnotetext{
${ }^{4}$ For example: Kosovo and Metohija (UN 1244) 40 years in prison before the possibility of applying for conditional release, Argentina and Peru 35, Philippines, Cuba, Estonia 30, Serbia and Israel 27, Italy 26, Albania, Northern Macedonia, Poland, Russia, Slovakia, Spain, South Africa 25, Turkey 24, France 18, Belgium, Germany, Greece, Switzerland 15, Cyprus, Denmark, Finland, Sweden 12, South Korea, Japan 10, Botswana and Ireland 7.
} 
there are a great number of other serious crimes, such as: other qualified forms of aggravated murder under Art. 114. CC, killing the representatives of the highest state bodies (Art. $310 \mathrm{CC}$ ), or grave acts against the constitutional system and the security of Serbia (Art. $321 \mathrm{CC}$ ) in which there is a possibility for conditional release of persons sentenced to life imprisonment, or, even, the crimes against humanity and other rights guaranteed by international law, e.g. genocide (Art. $370 \mathrm{CC}$ ) or crimes against humanity (Art. $371 \mathrm{CC}$ ) in which the act of execution may contain the acts of the crimes referred to in Article 46, paragraph 5, whereby convicted persons to life imprisonment would be given the possibility of conditional release.

However, the most important aspect of the prohibition of the possibility of conditional release of pertaining to life imprisonment is the potential violation of Article 3 of the European Convention on Human Rights (ECHR) and the jurisprudence of the European Court of Human Rights (ECtHR) for such a ban (Dimovski, Vujićič, Jovanović, 2019: 102).

The ECtHR jurisprudence has indicated in numerous cases that the existence of life imprisonment in the system does not present a form of torture, inhumane or degrading punishment or treatment, ${ }^{5}$ that is, prescribing life imprisonment in the national legal system does not constitute the violation of the Article 3 of the Convention. At the same time, the prohibition of the possibility of early dismissal or reviewing the sentence of life imprisonment constitutes inhumane or degrading punishment or treatment, that is, a violation of Article 3 of the ECHR. The practice of the ECtHR, therefore, is based on the premise that prisoners sentenced to life imprisonment must have "hope" and "path to release".

In one of the latest verdicts from March $12^{\text {th }} 2019$, in the case Petukhov v. Ukraine, the Court affirmed, inter alia, ,that there has been a violation of Article 3 of the Convention on the account of the applicant's irreducible life sentence". In the Grand Chamber Judgment of 9 July 2013, in the case Vinter and Others v. United Kingdom, the Court considers that "each life prisoner is entitled to know, at the outset of his sentence, what he must do in order to be taken into consideration for release and under what conditions, including when a review of his sentence will take place or when it may be sought. Consequently, where domestic law does not provide any mechanism or possibility for review of the whole life sentence, the incompatibility with Article 3 on this ground already arises at the moment of the imposition of the whole life sentence and not at a later stage of incarceration." casein the case of Kafkaris v. Cyprus, the Courtstates in para.103, that "notwithstanding, the Court does not find that life sentences in Cyprus are irreducible with no

\footnotetext{
${ }^{5}$ The Grand Chamber Judgment from February 122008 in the case Kafkaris v. Cyprus (Application no. 21906/04), pointed, in para. 97, that ,the imposition of a sentence of life imprisonment on an adult offender is not in itself prohibited by or incompatible with Article 3 or any other Article of the Convention."
} 
possibility of release; on the contrary, it is clear that in Cyprus such sentences are both de jure and de facto reducible." In the case Murray v. The Netherlands in para 104. it is stated that "life prisoners are thus to be provided with an opportunity to rehabilitate themselves. As to the extent of any obligations incumbent on States in this regard, the Court considers that even though States are not responsible for achieving the rehabilitation of life prisoners, they nevertheless have a duty to make it possible for such prisoners to rehabilitate themselves."

Another controversial normative solution is the length of conditional release for life prisoners who are eligible for a release. Namely, the essence of conditional release is that "part of the sentence is not served, that is, the execution of the remaining part of the sentence is only exceptional, ie. in cases of conditional release revocation, and if it does not occur the sentence is extinguished. During parole, punishment exists only as a legal possibility" (Stojanović, 2017: 230). However, Article 47 par. 7 of the CC provides that condional release lasts for fifteen years for life prisoners, and from the date of the release. Such a solution is completely illogical and contrary to the nature of the conditional release. However, other legal provisions do not specify what happens to a convicted person out of prison, after the expiration of fifteen years. Is it that the convicted, after that period, needs to (re)serve their sentence, so the release can be counted as a "life break" before the life of the convict ends in prison serving their sentence; or, perhaps, the idea of the legislator was to provide space for continual reconsideration of new conditional release terms for the remainder of the life prisoner's life. In any case, the law does not contain any more detailed provisions. We are of the opinion that there is no logical basis, neither criminal-political nor penological justification for temporarily limiting the duration of conditional release.

Finally, we will briefly touch upon the problem of the purpose of life imprisonment and the purpose of punishment. Life imprisonment is, according to its content, the punishment of an eliminating character with the purpose of excluding the sentenced person from society and incapacitating them for the rest of their life in terms of removing them from society into the confined prison space (if there is no possibility of conditional or early release). Consequentially, it cannot be expected that the purpose of this is the actual punishment prescribed in Article 42 of the CC. Without raising the questions of the purpose of punishment and the purpose of life imprisonment, due to the scope of this paper, we must point out that the Serbian legislator resorted to a "specific" decision that "complements" the purpose of the punishment. Namely, the new aim and purpose of the punishment, in the amended CC, is attaining justice (fairness) and proportionality between the crime and the gravity of the penalty.

Proportionality between crimes and punishment, and the satisfaction of the principle of justice in contemporary criminal law is achieved through 
the penal policy of the legislator by prescribing the type and (minimum and maximum) duration of the penalty for each individual incrimination. The imposition of "classical" or "bekarian" thinking in defining the "new" purpose of punishing appears to be the result of extorted legislative solutions. Justice and proportionality between gravity of the crime and penalty, now as the proclaimed principle (Ashworth, 2005: 102), on the one hand, attempts to create the impression of the necessity to return to a retributive and more punitive concept of punishment, while, at the same time, "justifying" the introduction of a severe sentence, such as life imprisonment. At the same time, the impossibility of resocialisation and social reintegration of the convicted person, as the proclaimed purpose of the execution of the imprisonment, will be compensated by the principles of justice and proportionality (Grujić et al, 2019).

\section{CONTEMPORARY SECURITY CHALLENGES THROUGH THE PRISM OF PREJUDICE, CRIME RATES AND TRENDS}

Considering the general criminal-political aspirations of the legislator in the recent period in the Serbian criminal law legislation, expansionism of the criminal law, the orientation towards the security aspect, the prescribing of new incriminations and the constant tightening and introduction of new penalties, all lead to a conclusion that our society faces strong security challenges and that the apparent response to these challenges is the harshness of criminal repression.

At the same time, the media content is filled with sensationalism when it comes to the topic of crime, and especially with regards to violent crime. Most of the media focuses on topics covering murder, rape, injury, abduction, extortion, acts of terrorism, acts of domestic violence or peer violence in order to popularize and commercialize their content. Without any empathy, on a daily basis, the media show blood and crime scenes, release entrusted information leaking from police sources, reconstruct the scenes of the crimes, publish photos of victims and reactions of victims' families, circulate images of violence posted on social networks and media, which, without other content dedicated to the topic of crime or criminality, results in a sense of general insecurity and vulnerability of the citizens.

Also, day-to-day activities of those performing public functions and politicians (or the pretenders to those positions) are aimed to "show strength" and a desire to "finally deal with criminals," promoting "zero tolerance of crime," "eradicating corruption" or similar phrases and metaphors used solely for increasing the popularity of these individuals and preserving their social or political positions (or hiding from criminal prosecution or concealing their own role in criminal activities or businesses). The media, as broadcasters of these statements, complement their sensationalist content on the topic of crime. Such a spiraling effect of interaction between the media, general 
public, interest groups and authorities is referred to as "moral panic" in literature (Ignjatović, 2018: 148).

However, we must point out that this is not the real, but a twisted picture of crime and criminality. The danger of crime is of much less relevance than it appears to be. Acts of violent crime, which most affect our prejudices about crime and their scale, represent only a small part of the overall structure of crime (Felson, 2011). Most of the reported crimes pertain to the area of property-related criminal acts, and many of them seem irrelevant and donot provoke a negative reaction from the general public. Moreover, most often they do not even require the initiation of the criminal justice mechanism.

The security challenges that our society faces are not dramatic, but contrary to that. This attitude is confirmed by the data on the crime rates and trends, as well as the structure of adjudicated crime, which will be addressed in the following section of the paper.

In accordance with the above, we will present data on the crime rates and trends in the Republic of Serbia from 2008 to 2018. We must emphasize that property crimes present more than half of the total number of reported crimes in the same period, which is a decades-long trend. In addition to that, because of the scope of this work we did not want to show this specific data separately. We wanted to focus on three groups of offenses, according to the chapters in the Special Part of the CC: crimes against life and body, criminal offenses against sexual freedom, as well as criminal offenses against marriage and the familly (because of one particular incrimination - domestic violence, Article 194 CC).

The average number of reported crimes annually during this period was 93,573 (Table 2). The highest number of crimes 108,759 was reported in 2015 , the lowest $74,279-2010$. At the beginning of the observed period in $2008,101,723$ crimes were reported, and at the end, in 2018, 92,802. If we consider the crime rates in the time lapse between 2008 and 2018, it can be concluded that the general trend of crime is decreasing. In this period, except for 2010 and 2011, when the lowest number of reported crimes is recorded due to the implementation of the "reform" of the judiciary, and in 2015, when the highest number of reports is recorded, the crime rate can be marked as stable, with a tendency to decrease, which is particularly evident for the period ofthe last three years: 2016, 2017 and 2018.

Crimes against life and body make up an average of $4 \%$ of the total reported crimes, although looking at media content, it could be assumed that this percentage is much higher. The highest reported number was 5,297 in 2008 , and the lowest 3,266 in 2014. The average number of reported crimes in absolute numbers is 3,823 cases annually in the observed period, compared to 93,573 of the total number of reported crimes. Offenses against life and body are characterized by a downward trend from $5.2 \%$ in 2008 to $3.3 \%$ in 2018. 
Sexual offenses account for an average of only $0.4 \%$ of reported crimes. The highest number was 448 in 2009, and the lowest 252 in 2014. The average number of reported crimes annually was 371 . The trend here is relatively stable, with a decrease in reported crimes from 2008 to 2014, followed by oscillation and then a slight increase until 2018.

For the crimes against marriage and family, there is an increasing trend. The lowest number of crimes was reported in $2008-5,250$, and the highest was 10,729 in the last observed year. The percentage share in the structure of reported crimes for the whole period is about $7.7 \%$, the lowest was recorded $5.2 \%$ in 2008, and the highest $11.5 \%$ in 2017. The reason for the increasing number of reports pertaining to crimes against marriage and family is the sharp increase in the number of reports of crime of domestic violence referred to in Article 194 of the CC. Namely, in 2008, 2,660 acts of domestic violence were reported, in 2011, 3,550, in 2013 it was 3,782 acts, in 2017 the number was 7,795, and in 2018 we notice the highest value with 7,916 crimes reported. In the observed period, the number of reports for this crime has almost tripled. An explanation for the phenomenon of such an increase in the number of acts of domestic violence is, among other things, the focus of society on domestic violence, the media coverage of this type of violence which affected the victims to be encouraged to report the crime, but also the preparation and the adoption of a special law that seeks to prevent this type of crime. Of course, it cannot be argued that this is a new phenomenon indeed. The relatively new incrimination of domestic violence has led to the "opening of the door of family home" and domestic violence is, therefore, no longer an unknown and disguised phenomenonbut is consequently being treated as a problem by the wider community, not just by the affected families or victims.

Table 2. Reported crimes in the Republic of Serbia 2008-2018

\begin{tabular}{lrrrrrrrrrrr}
\hline Reported Year & 2008 & 2009 & 2010 & 2011 & 2012 & 2013 & 2014 & 2015 & 2016 & 2017 & 2018 \\
Crimes Total & 101723 & 100026 & 74279 & 88207 & 92879 & 91411 & 92600 & 108759 & 96237 & 90384 & 92802 \\
\hline Against life & 5297 & 4912 & 3381 & 3908 & 3923 & 3734 & 3266 & 3818 & 3451 & 3278 & 3084 \\
and body & $5,2 \%$ & $4,9 \%$ & $4,6 \%$ & $4,4 \%$ & $4,2 \%$ & $4,1 \%$ & $3,5 \%$ & $3,5 \%$ & $3,6 \%$ & $3,6 \%$ & $3,3 \%$ \\
\hline Sexual & 405 & 448 & 387 & 414 & 372 & 320 & 252 & 352 & 367 & 338 & 427 \\
offences & $0,4 \%$ & $0,4 \%$ & $0,5 \%$ & $0,5 \%$ & $0,4 \%$ & $0,4 \%$ & $0,3 \%$ & $0,3 \%$ & $0,4 \%$ & $0,4 \%$ & $0,5 \%$ \\
\hline Against & 5250 & 5617 & 4657 & 5868 & 6182 & 6268 & 5914 & 7891 & 10190 & 10561 & 10729 \\
marriage and & $5,2 \%$ & $5,6 \%$ & $6,3 \%$ & $6,7 \%$ & $6,7 \%$ & $6,9 \%$ & $6,4 \%$ & $7,3 \%$ & $10,6 \%$ & $11,7 \%$ & $11,6 \%$ \\
family & & & & & & & & & & & \\
\hline
\end{tabular}

Source: Statistical Office of the Republic of Serbia

Table 3 presents data on the total number of persons who have been convicted in criminal proceedings, as well as data on convicted persons for the same three groups of crimes: against life and body, sexual freedom and marriage and family. The purpose of presenting this data is to present the participation of persons convicted of these crimes in the structure of adjudicated crime. They are also an indicator of the society's response to 
contemporary security challenges. Due to the volume of work, there was no analysis of data on the type of criminal sanctions imposed.

On average, between 2008 and 2018, 36,548 criminal sanctions were imposed annually. In relation to the average number of reported crimes, $39 \%$ of crimes were adjudicated. The highest number of court decisions was made in $2014-48,425$, and the lowest 21,681 in 2010. At the beginning of the observed period, 42,138 cases were adjudicated, and at the end of 2018 35,146. At first glance, it can be concluded that the trend of adjudicated crime is declining; however, the period is characterized by considerable fluctuations. There was a significant decline in 2010, then a slight increase in the next two years, then a sharp peak in 2014 , followed by a four-year downward trend.

The adjudicated crimes against life and body make up an average of $7.15 \%$ annually. The maximum percentage is recorded in the first observed year, 9.2\%, and the minimum in the last 2018. And in absolute numbers, it presents the same trend. The maximum number of judgments was 3,892 in 2008, a minimum of 1,691 in the last year. It can be stated that the trend of adjudicated crimes against life and body is declining.

When it comes to crimes against sexual freedom, they make up an average of $0.6 \%$ in the structure of sentencing, and this percentage is almost constant throughout the whole observed period. In absolute numbers, the highest number of verdicts was 256 in 2008, and the lowest164 in 2010. In the last three years, there has been a trend of a slight decline, which follows the trend of the decreasein the number of criminal sanctions pronounced.

Finally, crimes against marriage and family, due to the incrimination of domestic violence, show a growing trend of adjudicated crimes. The lowest percentage was recorded in 2008, 6.7\%, and the highest in 2018 $15.5 \%$. The average percentage participation is $10.2 \%$ of adjudicated crime. In absolute numbers, the minimum number of judgments was 2,842 and the maximum was 4,661 . The increasing trend is marked in the entire observed period, without oscillations, with a tendency of further increase.

Table 3. Sentenced for crimes in the Republic of Serbia 2008-2018

\begin{tabular}{|c|c|c|c|c|c|c|c|c|c|c|c|}
\hline Year & 2008 & 2009 & 2010 & 2011 & 2012 & 2013 & 2014 & 2015 & 2016 & 2017 & 2018 \\
\hline Total & 42138 & 40880 & 21681 & 30807 & 31322 & 32241 & 48425 & 42030 & 39610 & 37752 & 35146 \\
\hline Against life and & 3892 & 3410 & 1679 & 2320 & 2321 & 2397 & 2611 & 2074 & 1935 & 1913 & $\overline{1691}$ \\
\hline $\operatorname{limb}$ & $9,2 \%$ & $8,3 \% \%$ & $7,7 \%$ & $7,5 \%$ & $7,4 \%$ & $7,4 \%$ & $7,4 \%$ & $6,2 \%$ & $5,9 \%$ & $6,0 \%$ & $5,7 \%$ \\
\hline offences & 256 & 238 & 164 & 190 & 244 & 236 & 242 & 174 & 204 & 189 & 188 \\
\hline & $0,6 \%$ & $0,6 \%$ & $0,8 \%$ & $0,6 \%$ & $0,8 \%$ & $0,7 \%$ & $0,7 \%$ & $0,5 \%$ & $0,6 \%$ & $0,6 \%$ & $0,6 \%$ \\
\hline Agair & 2842 & 3251 & 1835 & 2891 & 2771 & 3102 & 3465 & 3512 & 3766 & 4400 & 4661 \\
\hline $\begin{array}{l}\text { marriage and } \\
\text { family }\end{array}$ & $6,7 \%$ & $8,0 \%$ & $8,5 \%$ & $9,4 \%$ & $8,8 \%$ & $9,6 \%$ & $9,8 \%$ & $10,6 \%$ & $11,6 \%$ & $13,9 \%$ & $15,5 \%$ \\
\hline
\end{tabular}

Source: Statistical Office of the Republic of Serbia 


\section{CONCLUSION}

The latest in a series of amendments to the $\mathrm{CC}$ has introduced the life imprisonment sentence into Serbian criminal legislation. At the same time, long-term imprisonment from thirty and up to forty years was abolished. Life imprisonment has assumed the role and function of the most rigorous imprisonment, although not enough time has elapsed since its introduction into the system so as to assess and review its effectiveness.

Bearing in mind that the period preceding the imposition of life imprisonment is characterized by the introduction of new incriminations, the toughening of penalties for existing offenses, the prohibition of mitigating sentences for certain offenses, the toughening of conditions for conditional release of prisoners, or, the widening of the retributive approach to punishment in general, it would be almost natural to assume that our society is facing serious security challenges and that such a reaction from the legislator was necessary.

However, such an assumption is incorrect and the retributive approach to punishment is not necessary. In support of this, the paper presents crime rates, trends and the structure of adjudicated crimes against life and body, sexual freedom and marriage and family in the period 2008-2018 as the main argument. With the exception of the increase in the number of reported and adjudicated crimes against marriage and family due to one crime - domestic violence, incriminated under Article 194 of the CC, other acts of violent nature do not have an upward trend. On the contrary, there is a decreasing trend.

The paper essentially opens the question of of why life imprisonment was introduced and what it is that can be expected from its implementation. The answer to this question is not simple, however. The authors of this paper have tried to emphasize the key elements on which the answer is based. Namely, the opportunity to introduce life imprisonment was not seized in 2002 after the death penalty was abolished, although most comparative criminal legislation also contains a sentence of life imprisonment in their systems. An attempt from 2015, when a draft amendment to the CC was introduced, which provided for the introduction of this sentence, was unsuccessful after serious criticism from the expert public and the Draft was withdrawn from the procedure. However, it was several of the monstrous crimes targeting children as victims and the activities of these victims' families that ensued that acted as decisive factors for the introduction of amendments to the CC, as well asof the life imprisonment sentence in 2019, without public hearing. Thus, without any analysis of the need for the introduction and the possible effects of life imprisonment as a punishment, the general public's urge to punish the perpetrators was satisfied. Criminal populism, as a postulate of state representatives, was thus accomplished.

Although the life imprisonment sentence has been introduced in the criminal sanctions system and its application has been enabled starting 
December 1, 2019, when the amended provisions come into force, the paper critically analyzes a number of controversial normative solutions that will, without a doubt, shortly hereafter be the subject of new amendments.

\section{REFERENCES}

Ashworth, A. (2005). Sentencing and Criminal Justice. New York: Cambridge University Press:

Convention for the Protection of Human Rights and Fundamental Freedoms, Rome, 4.XI.1950;

Krivični zakonik, Službeni glasnik RS, br. 85/2005, 88/2005 - ispr., 107/2005 - ispr., 72/2009, 111/2009, 121/2012, 104/2013, 108/2014, 94/2016 i 35/2019;

Grujić, Z; Blagić, D; Bojanić, B. (2019). Reexaming of justification for introduction of life imprisonment in Serbian criminal legislation. International Scientific Conference "Archibald Reiss Days" Thematic Conference Proceeding of International Significance. Belgrade: Academy of Criminalistic and Police Studies;

Dimovski, D; Vujičić, M; Jovanović, M. (2019). Doživotna kazna zatvora zakonodavstvo Srbije i međunarodni standardi. [Life imprisonment - Serbian legislation and international standards]. Pravna riječ. God. 16, br. 60, Banja Luka: Udruženje pravnika Republike Srpske;

Dragičević-Dičić, Radmila (2015). U susret izmenama Krivičnog zakonika. [The encounter to the amendments of the Criminal Code]. Bilten Vrhovnog kasacionog suda br. 2/2015, Beograd: Intermex;

Đokić, Ivan (2016). Reforma kazne zatvora u krivičnom zakonodavstvu Republike Srbije kazna zatvora u dugom trajanju ili doživotni zatvor? [Reforming the imprisonment in the criminal legislation of the Republic of Serbia - long-term imprisonment or a life imprisonment?]. Evropske integracije i kazneno zakonodavstvo (Poglavlje 23 - norma, praksa i mere harmonizacije). Zlatibor, Beograd: Srpsko udruženje za krivičnopravnu teoriju i praksu;

Felson, M. (2011). Zločin i svakodnevni život. [Crime and Everyday Life]. Prevod: Lukić, N. Beograd: Pravni fakultet;

Hirsch fon A. (1985). Past and Future Crime - Deservedness and Dangerousness in the Sentencing of Criminals. Oxford: The Alden Press;

Ignjatović, Đ. (2018). Kriminologija. [Criminology]. Beograd: Pravni fakultet;

Kafkaris v. Cyprus, Judgment 12 February 2008, (Application no. 21906/04);

Kostić, M. (2011). Ličnost maloletnog delinkventa - kriminološka obeležja. [Juvenile delinquen personality - criminological characteristic]. Teme, g. XXXV, br. 2;

Murray v. The Netherlands, Judgment 26 April 2016, (Application no. 10511/10);

Petukhov v. Ukraine (No. 2) Judgment 12 March 2019, (Application no. 41216/13);

Punoletni učinioci krivičnih dela, 2018. (2019). [Adult Offenders, 2018]. Saopštenje br. 192. [Report No. 192]. Beograd: Republički zavod za statistiku;

Punoletni učinioci krivičnih dela, 2012. (2013). [Adult Offenders, 2012]. Saopštenje br. 199. [Report No. 199]. Beograd: Republički zavod za statistiku;

Punoletni učinioci krivičnih dela u Republici Srbiji 2014 - prijave, optuženja i osude. (2015). [Adult Offenders in the Republic of Serbia 2014 - reports, charges and convictions]. Bilten br. 603. [Bulletin No. 603]. Beograd: Republički zavod za statistiku;

Punoletni učinioci krivičnih dela u Republici Srbiji 2017 - prijave, optuženja i osude. (2018). [Adult Offenders in the Republic of Serbia 2017 - reports, charges and convictions]. Bilten br. 643. [Bulletin No. 643]. Beograd: Republički zavod za statistiku; 
Risimović, R; Kolarić D. (2016). Redovno odmeravanje kazni. [Regular Sentencing]. Teme. g. XL, br. 1;

Ristivojević, B. (2013). „Punitivni populizam” srpskog zakonodavca: kritička analiza tzv. Marijinog zakona. ["Punitive populism" of Serbian lawmaker: a critical analysis of the so-called Mary's Law]. Nova rešenja u krivičnom zakonodavstvu Srbije $i$ njihova praktična primena. Zlatibor - Beograd: Srpsko udruženje za krivičnopravnu teoriju i praksu;

Soković, S. (2011). Savremene globalne tendencije u kontroli kriminaliteta (karakteristike, perspektive i osvrt na domaće prilike). [Contemporary global tendencies in crime control (characteristics, perspectives and reflection on domestic opportunities)]. Crimen (II) 2/2011;

Stojanović, Z. (2010). Krivičnopravni ekspanzionizam i zakonodavstvo Srbije. [Criminal law expansionism and Serbian legislation]. Kaznena reakcija u Srbiji i pravna sredstva reagovanja. IV deo. urednik Đ. Ignjatović. Beograd: Pravni fakultet;

Stojanović, Z. (2015). U susret Zakonu o izmenama i dopunama Krivičnog zakonika Srbije. [The encounter of the Law on Amendments to the Criminal Code of Serbia]. Suprotstavljanje savremenim oblicima kriminaliteta - analiza stanja, evropski standardi i mere za unapređenje. Tom I. Beograd: Kriminalističkopolicijska akademija, Fondacija „Hans Zajdel”;

Stojanović, Z. (2017). Komentar Krivičnog zakonika. [Commentary of the Criminal Code]. Beograd: Službeni glasnik;

The Rome Statute of the International Criminal Court, UN Doc. A\&CONF, 183/9, 17 July 1998;

„Tijana Đurić Foundation”. https://tijana.rs/fondacija/, Pristup: 30. september 2019;

Van Zyl Smit, Dirk; Appleton, Chaterine (2019). Life Imprisonment - A Global Human Rights Analysis. Cambridge-London: Harvard University Press;

Vinter and Others v. United Kingdom, Judgment 9 July 2013, (Applications 66069/09, 130/10, 3896/10);

Vuković, I; Đokić I. (2015). Obljuba zloupotrebom položaja nastavnika. [Sexual intercourse through abuse of position by teacher]. Teme. g. XXXIX, br. 3 .

\title{
КАЗНА ДОЖИВОТНОГ ЗАТВОРА КАО ОДГОВОР НА САВРЕМЕНЕ БЕЗБЕДНОСНЕ ИЗАЗОВЕ - (НЕ)АДЕКВАТНОСТ РЕТРИБУТИВНОГ ПРИСТУПА
}

\author{
Здравко В. Грујић \\ Универзитет у Приштини са привременим седиштем у Косовској Митровици, \\ Правни факултет, Косовска Митровица, Србија
}

\section{Резиме}

Последњом у низу измена и допуна КЗ у српско кривично законодавство уведена је казна доживотног затвора. Истовремено, укинута је казна дуготрајног затвора у трајању од тридесет до четрдесет година. Могло би се претпоставити да се наше друштво налази пред озбиљним безбедносним изазовима и да је таква реакција законодавца нужна и неопходна.

Међутим, таква претпоставка није тачна, а ретрибутивни приступ кажњавању није неопходан. Као аргумент претходно изнетом, у раду смо представили стопе 


\section{4}

криминалитета, трендове и структуру пресуђеног криминалитета код кривичних дела против живота и тела, полне слободе и брака и породице у периоду од 2008. до 2018. године. Изузев пораста броја пријављених и пресуђених кривичних дела против брака и породице због једне инкриминације - насиља у породици из члана 194 КЗ, остала дела насилничког карактера немају тенденцију раста. Напротив, бележи се тренд опадања.

Намеће се питање због чега је дошло до увођења казне доживотног затвора и шта се од њене примене може очекивати. Наиме, прилика да се уведе казна доживотног затвора није искоришћена приликом укидања смртне казне 2002. године. Покушај из 2015. године, када је представљен Нацрт измена и допуна КЗ у коме је било предвиђено увођење ове казне, након изнетих озбиљних критика стручне јавности био је неуспешан и Нацрт је повучен из процедуре. Међутим, неколико монструозних злочина, чије су жртве биле деца и активности њихових породица које су током уследиле, представљали су одлучујуће факторе да се у 2019. години, без одржавања јавне расправе, усвоје измене и допуне КЗ и казна доживотног затвора уведе у систем кажњавања. Тиме је без икакве анализе о потреби увођења и евентуалним ефектима доживотног затварања као казне задовољен порив опште јавности за репресивнијим кажњавањем злочинаца. Казнени популизам, као постулат представника власти, тиме је остварен.

Иако је казна доживотног затвора уведена у систем кривичних санкција и њена примена омогућена од 1. децембра 2019. година, када измењене одредбе ступају на снагу, у раду су критички анализирана бројна спорна нормативна решења, која ће, без икакве сумње, убрзо бити предмет нових измена и допуна. 